\title{
INVESTIGATING SUBSURFACE VOID SPACES AND GROUNDWATER IN CAVE HILL KARST USING RESISTIVITY
}

\author{
Jacob Gochenour, R Shane McGary, Gregory Gosselin, Ben Suranovic
}

Department of Geology \& Environmental Science, James Madison University, Memorial Hall, MSC 6903, 395 S.

High St., Harrisonburg, Virginia, 22801,USA, goche2ja@dukes.jmu.edu

\begin{abstract}
For this study, we selected two sites on Cave Hill at the Grand Caverns Natural National Landmark near Grottoes, Virginia, on the basis of existing surficial features, with the idea of exploring the connection between these features and the karstic subsurface using electrical resistivity (ER). The first of these, in the southern section of the hill, is a large swale. The second, a sinkhole located further north, was chosen in part because it is also the site of a U.S. Geological Survey (USGS) study investigating soil moisture content.
\end{abstract}

At the swale, the resistivity sections suggest that groundwater flows along bedding planes along the trend of an synform fold axis which is situated approximately parallel to and beneath the swale feature. For the resistivity lines crossing through the sinkhole, the inversion profile images show several potential perched aquifers, situated between the caverns and the sinkholes at the surface. The caverns were also imaged along with the water table approximately 70 meters below the surface.

The results indicate that bedding geometry and rock type are the dominant factors that define groundwater distribution and karstic features within Cave Hill. Specifically, a calcareous quartz arenite ridge defines a lithologic boundary with the limestone at which many of the sinkholes form and concentrated groundwater recharge appears to originate.

\section{Introduction}

Grand Caverns Natural National Landmark lies in the southeastern Shenandoah Valley of Virginia and is home to the oldest show cave in the United States. The park and adjacent private lands include a complex of at least five known caves: Grand Caverns, Madison Cave, Steger's Fissure, Jefferson Cave, and Fountain Cave, all within the northern section of Cave Hill karst. The cave complex lies below a series of sinkholes that run in two approximately north to south parallel lines.
The location of void spaces and water pathways in the subsurface can give insight into the structure of a specific karst environment, including the relationship between these and the epikarst. Electrical resistivity is particularly useful in locating these features because void spaces are more resistive and groundwater is more conductive than surrounding bedrock of low permeability (Palacky, 1987).

Figure 1 shows the two selected sites on Cave Hill and cross-section locations. At the swale at location 1, we collected seven 14 electrode (81 m) ER lines (Figure 2a), four running approximately perpendicular to the swale

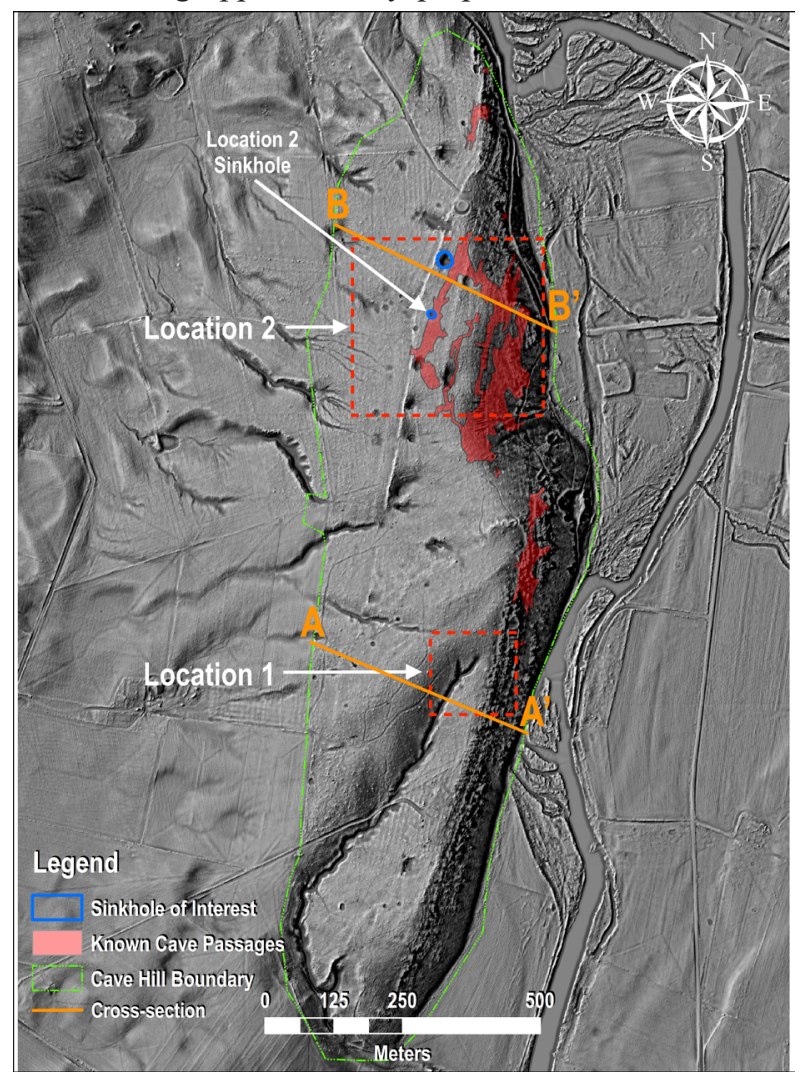

Figure 1. Locations of two surface features of interest on Cave Hill showing the combined hillshade + Topographic Positon Index (TPI) image, and known cave passage overlay. (Maps courtesy of D.H. Doctor, USGS.) 
(SW01-04) and three roughly parallel, one through the center (SW05) and one on each side (SW06 and SW07). For the sinkhole at location 2 (Figure 2b), we collected one 56 electrode ( $344 \mathrm{~m})$ ER line roughly parallel to a line defined by the westernmost series of sinkholes (GCDD09), and a 28 electrode (169 m) ER line perpendicular to the first and centered on the sinkhole (GCDD10). Centered on the selected sinkhole, the 56 electrode line also ran across a larger sinkhole to the north and adjacent to another sinkhole to the south. The
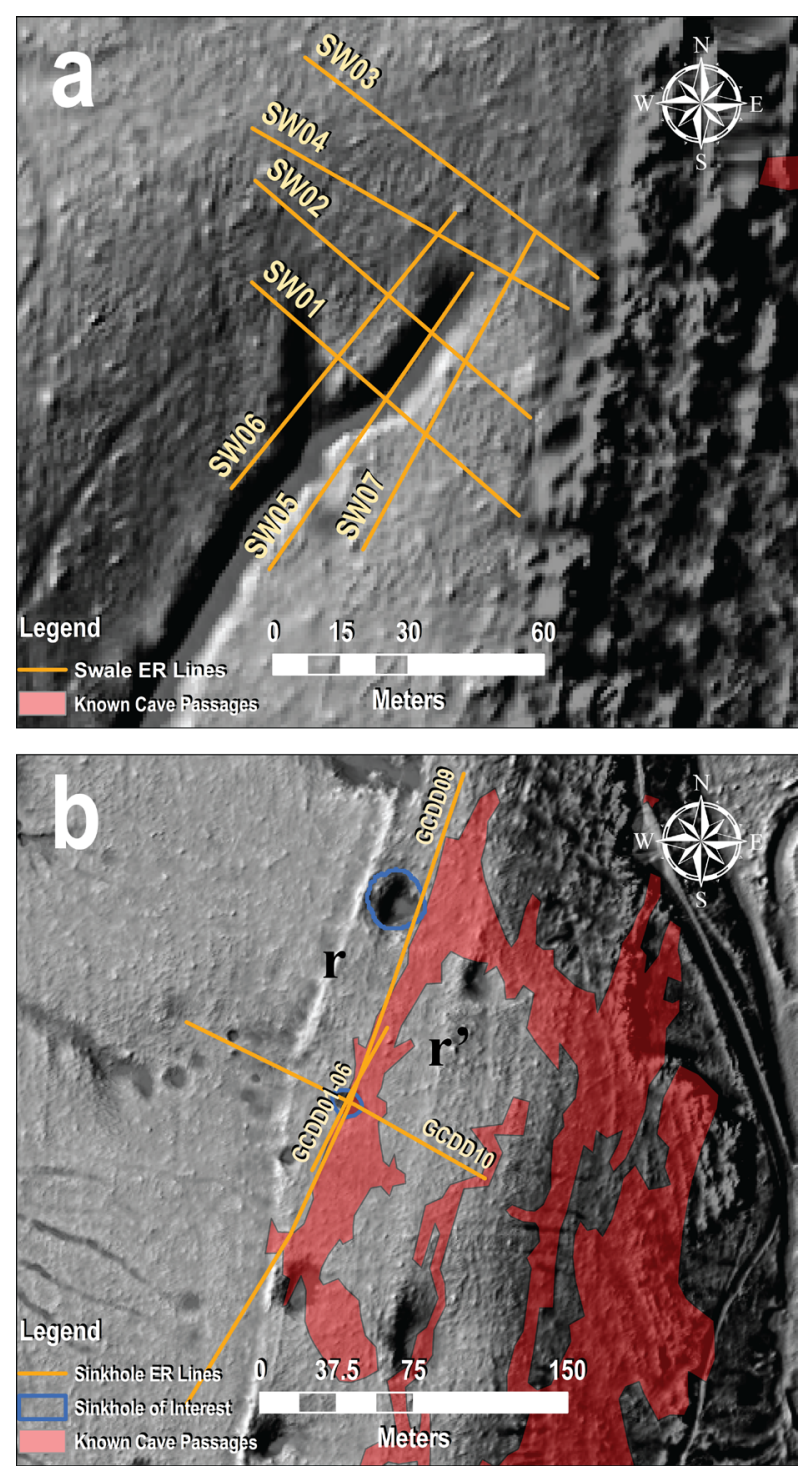

Figure 2. (A) ER lines deployed at location 1. (B) ER lines deployed at location 2. $r$ and r' represents calcareous arenite and dolostone ridges respectively. Background is a LiDARderived hillshade + TPI image and overlain with known cave passages (courtesy of D.H. Doctor, USGS). resulting ER images were interpreted within the context of geologic cross-sections, a high resolution airbornederived LiDAR digital elevation model (DEM), and known surface features and known cave passage locations at depth.

\section{Geological Setting}

The Shenandoah Valley is part of the Valley and Ridge province of Virginia, and is nestled between the Blue Ridge fault to the east and the Little North Mountain fault to the west. These faults are part of a western verging foreland fold and thrust belt formed during the Alleghenian Orogeny when Gondwana collided with Laurentia (Faill, 1998; Rader and Gathright, 2001). The valley is underlain by both siliciclastic and carbonate bedrock primarily deposited in marine environments during the Paleozoic (Rader and Gathright, 2001).

Within the valley bedrock are Cambrian and Ordovician carbonate units deposited as divergent continental margin (DCM) sediments between the rifting of the Rodinia supercontinent and Taconic Orogeny (Rader and Gathright, 2001). These DCM units consist of the Shady, Rome, Elbrook, Conococheague, Stonehenge, Beekmantown, New Market, and Lower Lincolnshire formations (Rader and Gathright, 2001).

Cave Hill is situated within the Cambrian age Conococheague Formation, which generally consists of laminated light- to dark-grey dolomitic limestone, thinly-bedded flat pebble conglomerate layers, coarsegrained calcareous quartz arenite, algal-laminated dolostone and limestone that frequently contains mudcracks, ribbon rock, and chert (Gathright et al., 1978). These sedimentary structures suggest deposition of the Conococheague was primarily influenced by cyclic eustatic sea-level changes within an environment that was dry and arid at times (Weber et al., 1995; Read and Repetski, 2012).

The South River flows alongside the eastern flank of Cave Hill. Much of the cavern passages within Cave Hill are located above river level; however, parts of Madison Cave and Steger's Fissure extend downward as deep as 30 meters below river level (Kastning, 1995). Doctor et al. (2014) suggest that both Grand Caverns and Madison Cave were phreatically formed due to the presence of subaqueous calcite coatings as well as local clay and silt sized sediments with an absence of foreign sand, 
gravel, and cobble sediments. The evolutionary biology of the phreatobytic crustacean Antrolana lira, commonly known as the Madison Cave isopod, found in Madison Cave and unique to the Shenandoah Valley, suggests the initiation of the formation of Cave Hill karst occurred a minimum of 20 million years ago (Hutchins et al., 2010; Doctor et al., 2014).

\section{Data \& Methods Electrical Resistivity}

All ER measurements were collected with the AGI SuperSting R-1 geoelectrical imager. For most lines, xyz-coordinates were collected at each electrode using a Leica Zeno 20 GPS unit. The Zeno 20 can obtain horizontal accuracy to $1 \mathrm{~cm}$ and vertical accuracy to three times the achieved horizontal accuracy. For most locations, we were able to collect good data; occasionally complicated by heavy cloud cover or overhead foliage. The suspect electrode locations and all elevation values were interpolated by using a 1 meter high resolution airborne LiDAR-derived digital elevation model (DEM) obtained from the USGS National Map website (https:// viewer.nationalmap.gov/basic/).

MeasuredER data were processed using AGI's EarthImager ${ }^{\circledR}$ 2D Resistivity and IP Inversion Software. We achieved the best results for each line using merged Schlumberger and Dipole-Dipole data sets for the inversions.

\section{Structural Geology and Geospatial Investigation}

We obtained strike and dip measurements from 17 outcrops on Cave Hill, and recorded observations of rock type and other notable characteristics such as sedimentary structure, fold patterns, and proximity to cave entrances. Trend and plunge of two fold axes were approximated using stereonets generated by Stereonet 9.9 (Allmendinger, Cardozo, and Fisher, 2013; Cardozo and Allmendinger, 2013).

We exported two elevation profiles across Cave Hill and perpendicular to the two fold axes from the Global Multi-Resolution Topography (GMRT) Grid Version 3.3 (Ryan et al., 2009) in GeoMapApp (Marine Geoscience Data System, 2013), which were used with the structural data to draw two cross-sections (Figure 3).

We imported the $1 \mathrm{~m}$ DEM into ArcGIS ${ }^{\circledR}$ to create a polyline shapefile representing the paths in which surficial water would flow on Cave Hill (i.e., artificial streams), using the hydrology tools for flow direction and flow accumulation from the Spatial Analyst toolbox. This result was combined with an elevation image of hillshade overlain by the topographic position index (TPI) and the cross-sections to correlate the inverted ER profiles with the surface features.

\section{Results \\ Structural Geology and Geospatial Investigation}

Bedrock near location 1 primarily consists of algal laminated dolostone and micrite. We determined the structure of the southern portion of Cave Hill consists of three higher-order folds within an overall anticline (Figure 3a), and we observed parasitic folding in algal laminated dolostone on the southeastern flank. The swale feature cuts through a syncline at the study location. Further South $(\sim 80 \mathrm{~m})$, the swale feature deviates

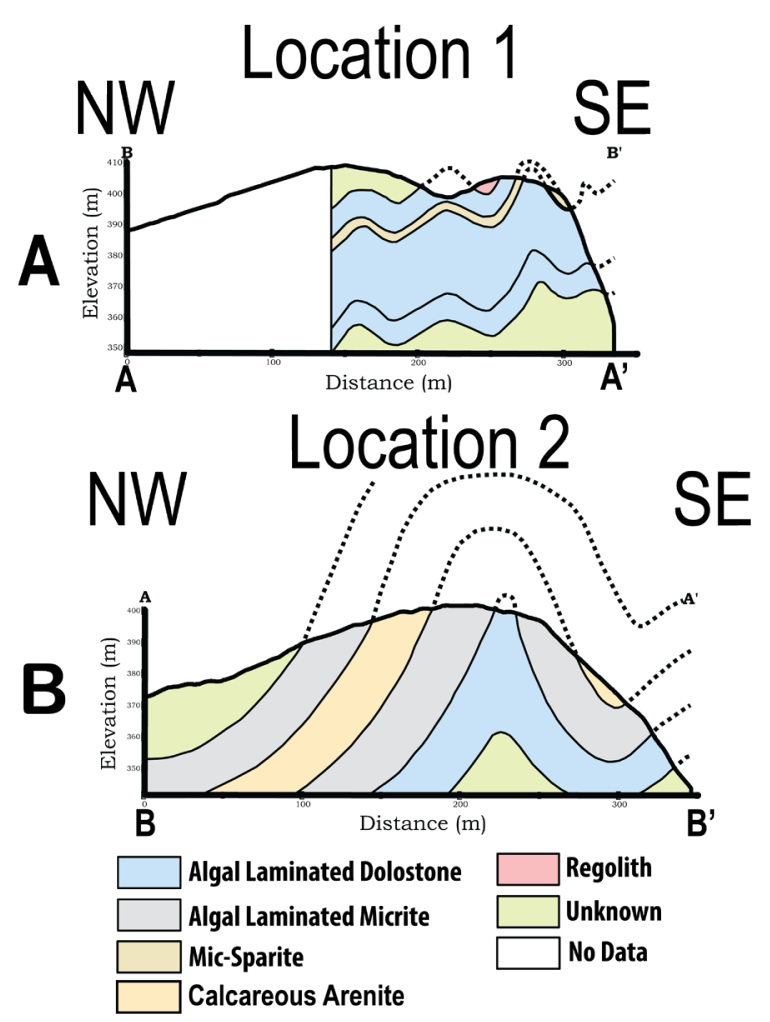

Figure 3. (A) Location 1 cross-section shows high-order folding within an overall syncline. (B) Location 2 cross-section shows sub-vertical bedding and an overall anticline. Refer to Figure 1 for cross-section location. A and B, after profiles exported from the GMRT Grid Version 3.3 (Ryan et al., 2009) in GeoMapApp (Marine Geoscience Data System 2013). 
westward from strike $(\sim 30 \mathrm{~m})$ and begins to cut through the antiform axial fold.

Bedrock near location 2 consists of algal laminated micrite, algal laminated dolostone, and calcareous arenite. The rock units here are incorporated into an anticline-syncline pair (Figure $3 b$ ). A thick bed of micrite located between calcareous arenite to the west and algal laminated dolostone to the east lies under the ER deployment area. Survey GCDD09 crossed diagonally $\left(\sim 20^{\circ}\right)$ over the arenite bed.

The artificial streams generated from the DEM indicate that surface water flows into the swale feature (location 1) primarily from the northwest (Figure 4). This is consistent with the stereonets we generated from the geologic data, showing that the fold axis on the southeastern flank of Cave Hill, near location 1, trends $\sim 206^{\circ} \mathrm{SSW}$ and plunges $\sim 15^{\circ}$, while the fold axis on the western flank, near location 2 , trends $\sim 214^{\circ} \mathrm{SSW}$ and plunges $\sim 20^{\circ}$. The swale deviates the surface water along strike to the SSW where it is able to flow freely into a local stream. Surface water at location 2 flows to the northwest; however, a calcareous arenite ridge, identified both in the field and with the aid of a hillshade + TPI map, appears to block most surface water from flowing directly into local streams. Instead, surface water is forced into the subsurface through sinkholes located along the eastern side of the ridge. There is also a second parallel ridge located to the East $(\sim 50 \mathrm{~m})$ that appears to be acting in a similar manner.

\section{Electrical Resistivity Near the Swale}

The 14 electrode lines we deployed at this site resolved the resistivity structure to a depth of slightly less than 20 meters. The background resistivity for all sections ranged from semi-conductive (333-1,000 $\Omega \mathrm{m}$ ) (Figure 5, [a]) to moderate values $(\sim 1,000-3,333 \Omega \mathrm{m})$ (Figure 5, [b]).

Horizontal to sub-horizontal oblong conductive features $(<333 \Omega \mathrm{m})$ are present within the upper subsurface $(<10 \mathrm{~m})$ (Figure 5, [c]); section SW06M has a single conductive layer extending across the entire section (Figure 5b, [SW06], [c]). Deeper in the subsurface ( $\geq 10 \mathrm{~m})$, sections SW01M, SW03M, SW04M, SW05M, and SW06M show resistive features $(>3,333 \Omega \mathrm{m})$ towards the edge of our depth resolution (Figure 5, [d]). Sections SW02M, SW03M, and SW06M each contain one resistive $(>3,333 \Omega \mathrm{m})$ small ovoid feature in the upper subsurface (Figure 5, [d']).

\section{Electrical Resistivity Near the Sinkhole}

We were able to resolve the resistivity structure to approximately 82 meters for GCDD09M and 40 meters for GCDD10M. The sections all consisted of moderate background resistivity values $(1,000-6,250 \Omega \mathrm{m})$ (Figure 6, [b]). The upper-subsurface $(<10 \mathrm{~m}$ depth) contains a band ( $\sim 5 \mathrm{~m}$ thick) of horizontally to subhorizontally oriented semi-conductive (250-1,000 $\Omega \mathrm{m})$ to conductive oblong features $(<250 \Omega \mathrm{m})$ (Figure 6 , [c]). The angle of orientation of the conductive bands become steeper $\left(\sim 15^{\circ}-60^{\circ}\right)$ and thickness generally increases from topographic high areas towards sinkhole features at which they plunge to deeper depths $(\sim 25 \mathrm{~m}$ depth) (Figure 6, [c']). Jagged semi-conductive layering $(625-1,000 \Omega \mathrm{m})$ is present in the deepest portions of GCDD09M ( 65-82 m depth) (Figure 6a, [c"]).

Resistive ovoid shaped features $(\sim 6,250-10,000 \Omega \mathrm{m})$ are oriented under the conductive bands ( $\sim 10-16 \mathrm{~m}$ depth) such that their major axes ( 6-20 m length) are parallel to the sides of the sinkhole (Figure 6a, [d']). At depth

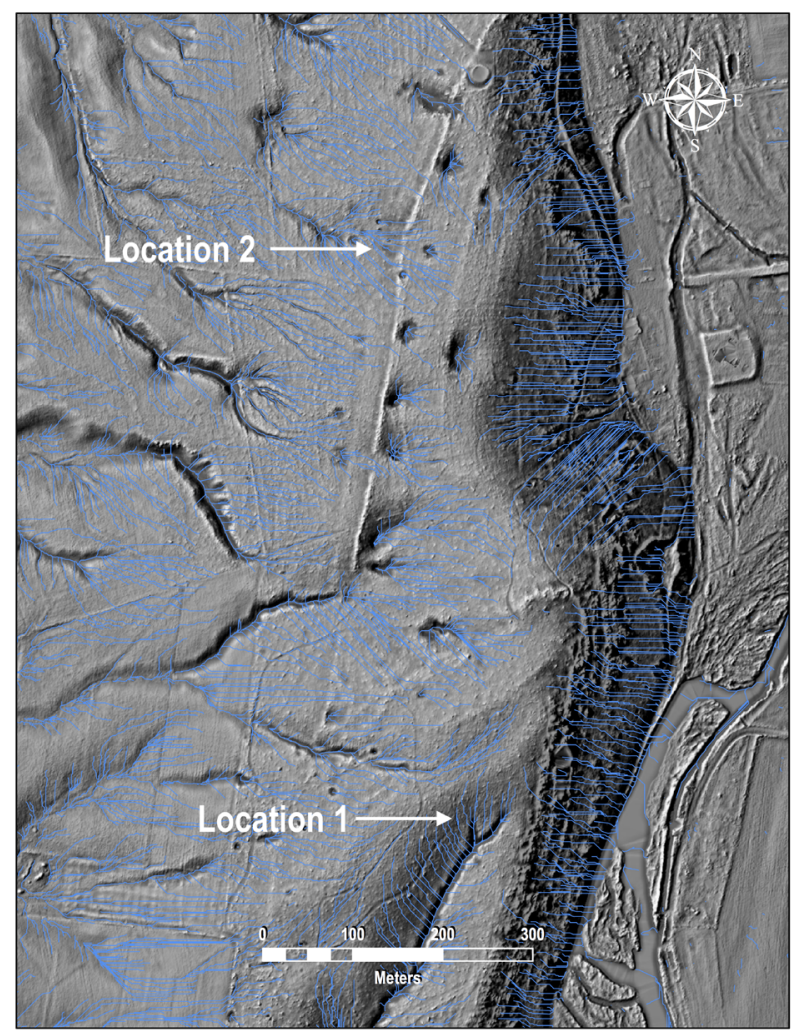

Figure 4. Artificial streams representing the paths in which surficial water would flow on Cave Hill. Background is a LiDAR-derived hillshade + TPI image (courtesy of D.H. Doctor, USGS). 


\section{A}

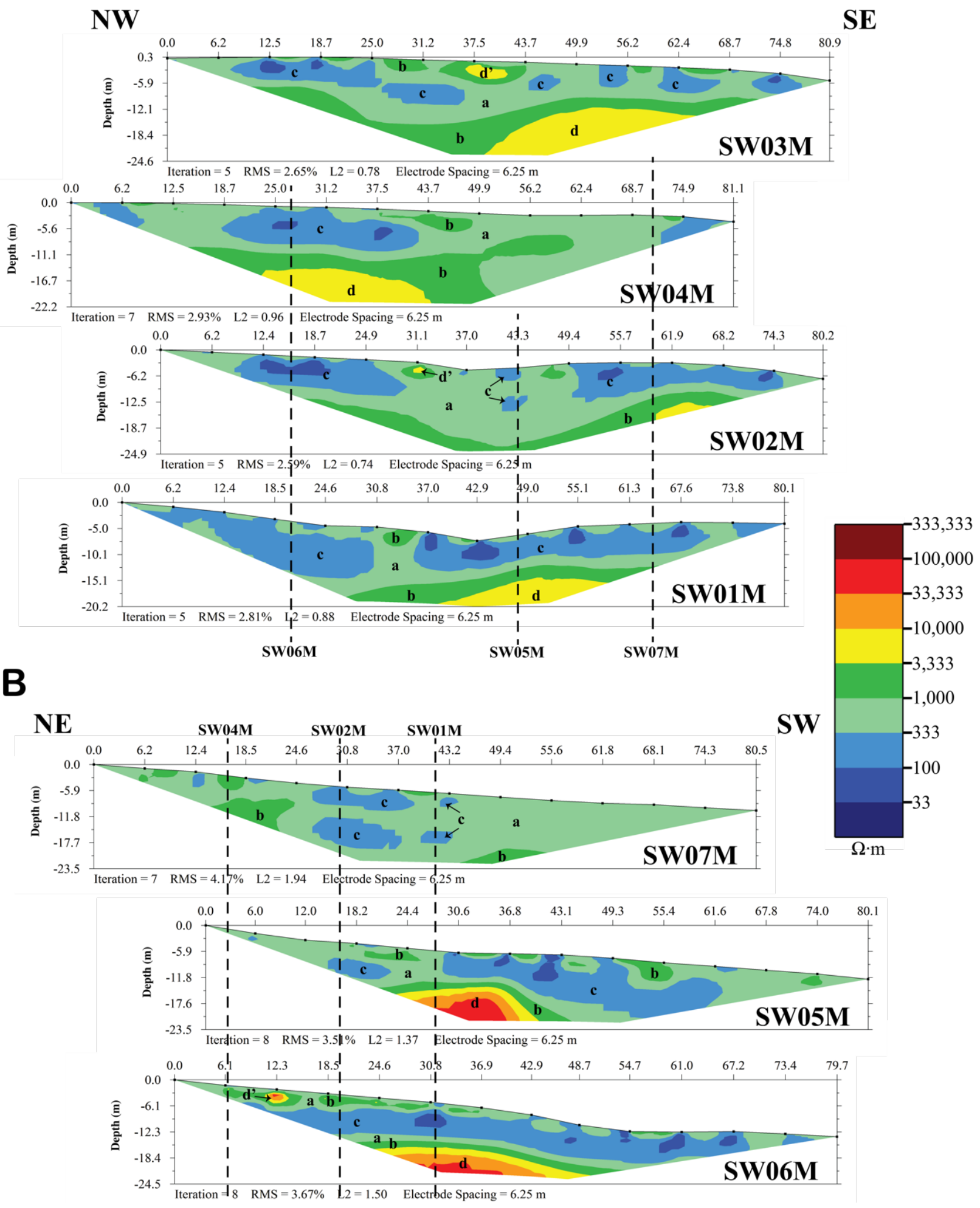

Figure 5. Location 1 ER sections. (A) southeast to northwest sections situated approximately perpendicular to the swale feature. (B) northeast to southwest sections situated approximately parallel to and within the swale feature. 
$(\sim 16-45 \mathrm{~m})$, are larger resistive $(\sim 6,250-25,000 \Omega \mathrm{m})$ ovoid features ( $\sim 30-50 \mathrm{~m}$ length) (Figure $6 \mathrm{a},[\mathrm{v}])$. There is an area on the southwestern side of GCDD09M that contains an extremely-resistive ovoid feature ( $>100,000 \Omega \mathrm{m}$ ) oriented between two conductive bands (Figure 6a, [d"]).

\section{Discussion}

Soil survey data suggests the soil profile consists of eroded loam to silty loam and is approximately 1.83 meters thick through the B horizon (USDA, 2016). Since the soil profile is thin, its presence can generally be excluded from the ER sections; although it is a component in regolith, which is made up of soil and weathered bedrock. Loam has resistivity values between 20 and $160 \Omega \mathrm{m}$ (Angenheister 1982), and limestone and dolomite are generally 1,000 $\Omega \mathrm{m}$ (Palacky, 1987; Stepišnik, 2008; Ishmail and Anderson, 2012), but can range as high as 100,000 $\Omega \mathrm{m}$ (Palacky, 1987). Stepišnik (2008) reported limestone rubble and soil containing weathered bedrock to range between 200 and 1,000 $\Omega \mathrm{m}$. Ishmail (2012) stated the transition zone between soil and bedrock can range between 105 and $900 \Omega \mathrm{m}$.

The resistivity value of all subsurface material is dependent on how water saturated the material is (Palacky, 1987), and decreases almost uniformly with increasing water saturation (Suau and Spurlin, 1982). Therefore, we interpret highly-saturated, saturated, and little- to non-saturated regolith to be $<1,000 \Omega \mathrm{m}$. Zhu et al. (2011) showed, with borehole conformation, that ER was successful in finding water saturated areas, but could not distinguish between water filled conduits and saturated ground with ER alone, which will not be attempted by this study.

Knowing that limestone resistivity can be as high as $100,000 \Omega \mathrm{m}$, we can deduce that values greater than this are likely open air voids. Open air void spaces and caves are generally considered to have higher resistivity than the surrounding bedrock due to the near-infinite resistivity of air (Gibson et al., 2004; Mitrofan et al., 2007; Chalikakis et al., 2011; Ismail and Anderson, 2012; Martínez-Moreno, 2014). Models compared to ER sections with known caves by Martínez-Moreno (2014) suggested that caves should be irregular to ovoid shaped and increase in resistivity from the edges to the center.

\section{Location 1, Karstic Swale}

We interpret the near surface conductive features in these sections to represent regolith or weathered bedrock (with increased clay mineral content), through which water would be able to infiltrate. This is evident from the correspondence of conductive anomalies between SW06M and SW05M with SW01M, SW02M, and SW04M (Figure 5), and is similar to the results produced by Roningen and Burbey (2012) and Carriere (2013). This flow direction is consistent with what we would expect given the antiform fold axis plunge. The isolated conductive area of SW07M (Figure 5b [SW07M], [c])

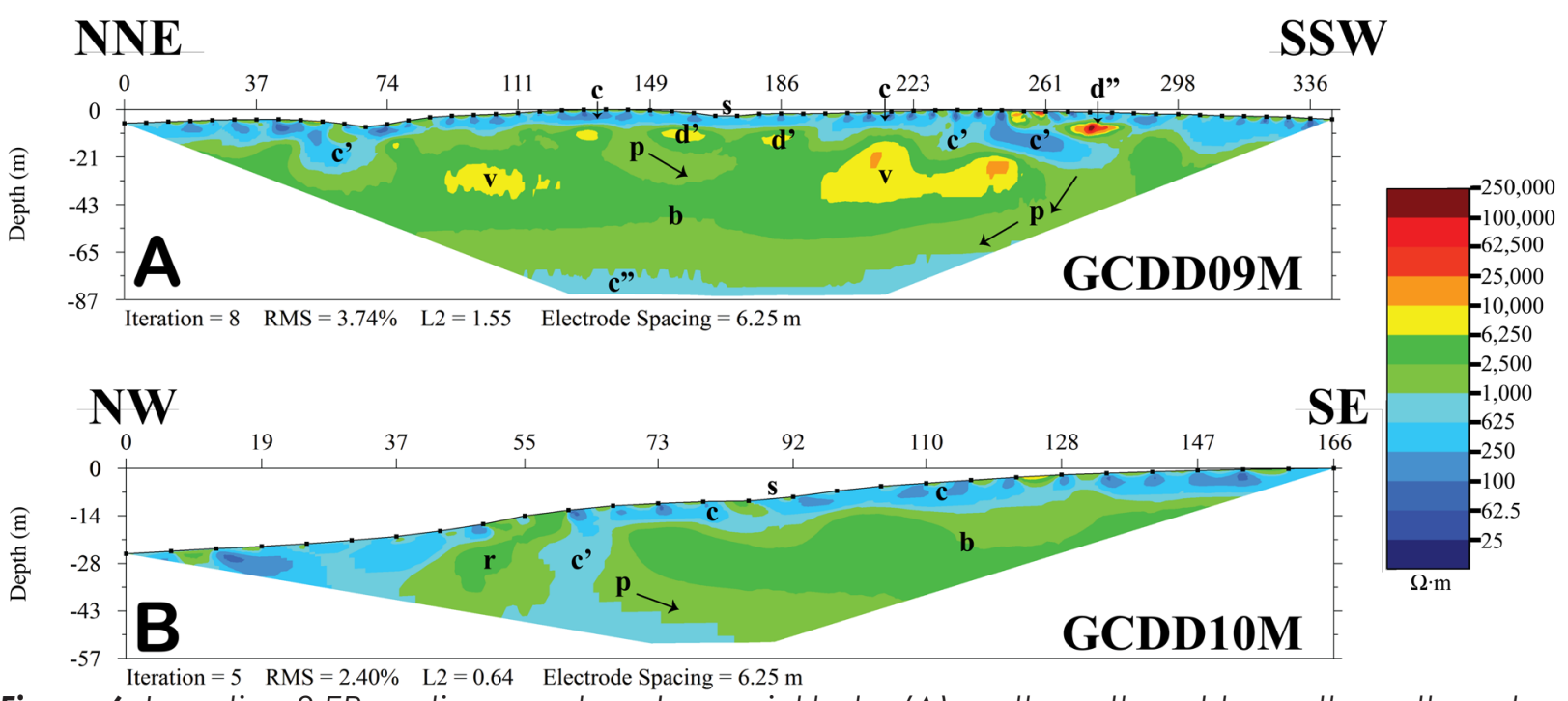

Figure 6. Location 2 ER sections centered over sinkhole. (A) north-northeast to south-southwest 56 electrode section (B) southeast to northwest 28 electrode section. s marks the location of the USGS soil moisture survey. 
along with the near absence of bedrock seems to indicate that water infiltrates downward through unconsolidated material until it reaches and flows along bedrock. Resistive to highly-resistive anomalies (Figure 5, [d] d) are possibly permeable bedrock beneath the areas of weathered bedrock near the surface. It is possible that the more resistive of these features are sampling open air void spaces or caves either too deep to resolve or slightly off line, but this cannot be shown conclusively.

\section{Location 2, Caverns}

We interpret the conductive regions near the surface (Figure 6, [c]) to be semi-saturated to saturated soil and regolith, with the bottom of the conductive regions marking the transition into bedrock. In some places (Figure 6, [c']), the conductive regions penetrate the bedrock to depths of as much as ten meters, forming a network of preferred groundwater pathways or perched aquifers (the $2 \mathrm{~d}$ nature of the survey make it impossible to distinguish between these two possibilities). Three of these features are situated under sinkholes that have formed along the eastern side of a calcareous arenite ridge (Figure 2b, [r]; Figure 6b, [r]), which dips $\sim 69^{\circ}$ NW. A second dolostone ridge exists approximately 50 meters to the east (Figure $2 \mathrm{~b},\left[\mathrm{r}^{\prime}\right]$ ), with a second row of sinkholes to the east of that ridge; it seems likely that similar aquifers exist here as well, especially given the presence of caverns below (Figure 2b), but our lines did not extend this far southeast. The calcareous arenite ridge that is included in our survey appears to interrupt the flow of surface and shallow groundwater flow to the west/northwest, causing the water to infiltrate into the ground at its eastern boundary as shown by the aquifer (Figure 6b, [c']), the largest and deepest saturated area between the two ridges. Furthermore, the specific placement of the sinkholes along the ridge seems to be associated with the portions of the ridge that are more strongly detectable at the surface; the DEM artificial stream models show that sinkholes have not formed where the surface water is able to penetrate the ridge.

The infiltrating water images in Figure $6 \mathrm{~b}$ reaches depths at the limits of resolution (nearly $50 \mathrm{~m}$ ), and likely continues past the capillary fringe and into the water table approximately $70 \mathrm{~m}$ below the surface (Figure 6a, [c"], equivalent to the depth of the river that runs at the base of the hill. Between the aquifers and the water table, we note several resistive features (Figure 6a, [d', v]) that partially capture portions of the known cavern complex below (at least in the case of [v]; the features in [d'] are likely smaller, shallower, and previously undetected void/ partially void spaces. These anomalies have higher resistivity than the surrounding bedrock, but they are not as high as what is expected for an open air cave. This is likely due to the lines being on the edge and/or slightly offset from the known cave passages. An additional small highly resistive feature (Figure 6a, [d"]) is likely a void space, either being more genuinely resistive than the $[\mathrm{v}]$ features, or more directly sampled. The bedrock seems to exist at a range of resistivity (Figure 6, [b]), from approximately 1,000 $\Omega \mathrm{m}$ to 6,250 $\Omega \mathrm{m}$. The more conductive regions may directly correspond to the more saturated areas, and while to some extent this could be an artifact of the smoothing process inherent in the inversion, it could also identify groundwater pathways through the carbonate bedrock from the aquifers to the caves and/or water table below (Figure 6, [p]).

\section{Conclusions}

This study provides significant insight to the factors governing surface and groundwater transport, sinkhole formation, and cave formation at Cave Hill. We found these features to be largely determined by rock type and bedding orientation, which differs from location to location, leading to the formation of different surface features and different water pathways and void geometries in the subsurface.

At the swale, we were able to show a clear image of the surface water and shallow subsurface groundwater flow, with water in the saturated regolith appearing to flow along bedding planes in the approximate direction of an antiform plunge. Our data did not sample to depths required to image the full karst system at this location, and therefore we are not able to confirm the presence of any void spaces, despite the higher resistivities towards the bottom of the sections that might suggest their existence. We were also not able to show the water pathways all of the way from the surface to the water table.

At the sinkhole, ridges, formed from rock less prone to dissolution, block the surface runoff of rain and meltwater, and force groundwater infiltration on the western flank of the ridges along the steeply dipped bedding planes. Over time, dissolution increases the porosity the carbonate bedrock, ultimately causing the formation of voids and sinkholes. This process, along with a fluctuating water table, helped to carve out the large cavern complex we see today. 


\section{References}

Allmendinger RW, Cardozo NC, Fisher D. 2013. Structural geology algorithms: vectors \& tensors: Cambridge, England, Cambridge University Press, p. 289.

Angenheister G, editor. 1982. Physical properties of rocks. In: Landolt-Börnstein, New series: $1 \mathrm{~b}$. Springer-Verlag.

Cardozo N, Allmendinger RW. 2013. Spherical projections with OSXStereonet: Computers \& Geosciences (51), no. 0: 193-205.

Carrière SD, Chalikakis K, Sénéchal G, Danquigny C, Emblanch C. 2013. Combining Electrical Resistivity Tomography and Ground Penetrating Radar to study geological structuring of karst unsaturated zone. Journal of Applied Geophysics (94): 31-41.

Chalikakis K, Plagnes V, Guerin R, Valois R, Bosch FP. 2011. Contribution of geophysical methods to karst-system exploration: an overview. Hydrogeology Journal (19): 1169-1180.

Doctor DH, Orndorff W, Maynard J, Heller MJ, Casile GC. 2014. Karst geomorphology and hydrology of the Shenandoah Valley near Harrisonburg, Virginia. In: Bailey CM, Coiner LV, editors. Elevating geoscience in the southeastern United States: new ideas about Old Terranes. Field Guides for the GSA Southeastern Section Meeting; Blacksburg, Virginia. Geological Society of America Field Guide (35): 161-213.

Faill RT. 1998. A geologic history of the north-central Appalachians; Part 3, the Alleghany Orogeny. American Journal of Science (298): 131-179.

Gathright TM II, Henika WS, Sullivan III. 1978. Geology of the Grottoes quadrangle, Virginia: Virginia Division of Mineral Resources Publication 10, 1:24,000 map with text.

Gibson PJ, Lyle P, George DM. 2004. Application of resistivity and magnetometry geophysical techniques for near-surface investigations in karstic terranes in Ireland. Journal of Cave and Karst Studies 66 (2): 35-38.

Hutchins B, Fong DW, Carlini DB. 2010. Genetic Population structure of the Madison Cave isopod, Antrolana lira (Cymothoida: Cirolanidae) in the Shenandoah Valley of the eastern United States. Journal of Crustacean Biology 30 (2): 312-322.

Ismail A, Anderson N. 2012. 2-D and 3-D resistivity imaging of karst sites in Missouri, USA. Environmental \& Engineering Geoscience 18 (3): 281-293.

Kastning EH III. 1995. Evolution of a karstic groundwater system, Cave Hill, Augusta County, Virginia: a multi-disciplinary study. In: Beck BF, editor. Karst GeoHazards: Rotterdam, Balkema, p. 141-148.

Marine Geoscience Data System. 2013. GeoMapApp (3.6.0) [software]; Lamont-Doherty Earth Observatory, Columbia University, Pallisades, New York, http://www.geomapapp.org/.

Mitrofan H, Povarä I, Mafteiu M. 2008. Geoelectrical investigations by means of resistivity methods in karst areas in Romania. Enviorn Geol (55): 405-413.

Martínez-Moreno FJ, Galindo-Zaldívar J, Pedrera A, Teixido T, Ruano P, Peña, González-Castillo L, Ruiz-Constán A, López-Chicano M, MartínRosales W. 2014. Integrated geophysical methods for studying the karst system of Gruta de las Maravillas (Aracena, Southwest Spain). Journal of Applied Geophysics (107): 149-162.

Palacky GJ. 1987. Resistivity characteristics of geologic targets In: Nabighian MN, editor. Electromagnetic methods in applied geophysics: volume 1, theory. Society of Exploration Geophysicists. p. 52-129.

Rader EK, Gathright TM II. 2001, Geologic map of the Augusta, Page, and Rockingham Counties portion of the Charlottesville $30 \times 60$ minute quadrangle: Virginia Division of Mineral Resources Publication 159.

Read JF, Repetski JE. 2012 Cambrian -lower Middle Ordovician passive carbonate margin, southern Appalachians. In: Derby JR, Fritz RD, Longacre SA, Morgan WA, Sternbach CA, editors. The great American carbonate bank: the geology and economic resources of the Cambrian-Ordovician Sauk megasequence of Laurentia: AAPG Memoir (98): 357-382.

Roningen JM, Burbey TJ. 2012. Hydrogeologic controls an lake level: a case study at Mountain Lake, Virginia, USA. Hydrogeology Journal (20): 1149-1167.

Ryan WBF, Carbotte SM, Coplan JO, O'Hara S, Melkonian A, Arko R, Weissel RA, Ferrini V, Goodwillie A, Nitsche F, Bonczkowski J, Zemsky R. 2009. Global multi-resolution topography synthesis. Geochem. Geophys. Geosyst. (10): Q03014.

Stepišnik U. 2008. The application of electrical resistivity imaging in collapse doline floors: Divaca Karst, Slovenia. Studia Geomorphologica Carpatho-Balcanica (42): 41-51.

Suau J, Spurlin J. 1982. Interpretation of micaceous sandstones in the North Sea: Proc. Soc. Prof. Well Log Analysts 23rd Annual Meeting. p. 1-32.

USDA: Natural Resources Conservation Service Web Soil Survey [Internet]. 2017. U.S. Department of Agriculture; [data cited 2017 Sep 15]. Available 
from: https://www.nrcs.usda.gov/wps/portal/nrcs/ site/soils/home/.

USGS National Map 1 meter DEM Elevation Products available from: https://viewer.nationalmap.gov/ basic/ [Accessed 2017 Sept. 15].

Weber LJ, Sarg JF, Wright FM. 1995. Sequence stratigraphy and reservoir delineation of the Middle Pennsylvanian (Desmoinesian), Paradox Basin and Aneth field, southwestern U.S.A. In: Read JF, Kerans C, Weber LJ, Sarg JF, Wright FM, editors. Milankovitch sea-level changes, cycles, and reservoirs on carbonate platforms in greenhouse and ice-house worlds: SEPM Short Course (35), Part 3: 1-81.

Zhu J, Currens JC, Dinger JS. 2011. Challenges of using electrical resistivity method to locate karst conduits- a field case in the Inner Bluegrass Region, Kentucky. Journal of Applied Geophysics (75): 523-530. 
